\title{
The cross-sectional area of the superficial digital flexor tendon of trained and untrained Thoroughbred racehorses
}

\author{
Área transversal do tendão flexor digital superficial de cavalos Puro Sangue Inglês de \\ corrida em treinamento e sem treinamento
}

Ana Guiomar Matos Santiago Reis ${ }^{1}$ Raquel Yvonne Arantes Baccarin ${ }^{1^{*}}$

\begin{abstract}
Twenty Thoroughbred racehorses were ultrasonographically evaluated to determine the relation between normal values of the cross-sectional area (CSA) of the right and left forelimbs superficial digital flexor tendons (SDFT) in the metacarpal region for trained and untrained Thoroughbreds racehorses. Ultrasonography revealed that CSA at $26 \mathrm{~cm}$ distal to the accessory carpal bone is larger than other proximal levels, for either left or right forelimbs. In addition, the CSA at 2, 4, 6, 8, 10,12 and $14 \mathrm{~cm}$ distal to the accessory carpal bone of the left forelimb are larger $(P<0.05)$ for trained horses when compared with untrained horses. On the other hand, there was no significant difference $(P>0.05)$ between left and right forelimb for CSA of the SDFT, at any level, for either trained or untrained horses, and there was no significant difference between untrained or trained horses for the CSA of right forelimb. In conclusion, the CSA of the left forelimb SDFT for horses that had been in continuous race training remains larger when they were trained anticlockwise, contrary to horses that had not been training for more than one year.
\end{abstract}

Key words: equine, tendon, ultrasound, cross-sectional area.

\section{RESUMO}

Vinte cavalos da raça Puro Sangue Inglês de corrida foram submetidos a exame ultrassonográfico, com o intuito de determinar a relação entre os valores normais da área do tendão flexor digital superficial (TFDS) na região metacarpiana dos membros torácicos direito e esquerdo, em cavalos com e sem treinamento. O exame ultrassonográfico revelou que a área do tendão $26 \mathrm{~cm}$ distal ao osso acessório do carpo é maior em comparação com as alturas proximais, tanto nos membros torácicos esquerdos, como nos membros torácicos direitos. Além disso, a área do TFDS nas alturas 2,
4, 6, 8, 10, 12 e 14cm, no membro torácico esquerdo, é maior $(P<0,05)$ nos cavalos em treinamento do que nos cavalos sem treinamento. Entretanto, não houve diferença $(P>0,05)$ nas áreas do TFDS entre os membros torácicos direito e esquerdo, tanto para os animais em treinamento, como para os animais sem treinamento. Também não foi encontrada diferença significativa em comparação com o membro direito dos cavalos em treinamento e sem treinamento. Conclui-se que os cavalos mantidos em treinamento permanecem com a área do TFDS maior no membro torácico esquerdo quando são treinados no sentido anti-horário das pistas de corrida, diferentemente do que ocorre com os cavalos afastados do esporte por mais de um ano.

Palavras-chave: equino, tendão, ultrassom, área transversal.

\section{INTRODUCTION}

Diagnostic ultrasonography was introduced in the early 1980s as a practical imaging modality to evaluate soft tissue inquiries of the equine limb (RANTANEN, 1982), now it is the imaging modality of choice for soft tissue evaluation (RANTANEN et al., 2003).

The use of diagnostic ultrasound to detect and monitor equine tendon injuries has greatly improved veterinarians' capacity to accurately diagnose the presence and extent of soft tissue injury and to monitor the progress of healing (GENOVESE et al., 1990).

'Departamento de Clínica Médica, Faculdade de Medicina Veterinária e Zootecnia (FMVZ), Universidade de São Paulo (USP), 05508-270, São Paulo, SP, Brasil. E-mail: baccarin@usp.br. *Autor para correspondência. 
Changes on ultrasonographic examination as hypoechogenic core lesions, poor fiber alignment, and obvious increase in cross-sectional area (CSA) confirm incipient or actual clinical lesions (GILLIS et al., 1993; REEF, 1998). An accurate knowledge of ultrasonographic characteristics of tendons is necessary (REEF, 2001) to allow the veterinarian to differentiate between normal and abnormal ultrasonographic patterns (GILLIS et al., 1995). Thus, to differentiate normal from abnormal, examiners need baseline values for the structures of interest.

As there is no controlled study of ultrasonographic examination of the cross-sectional area (CSA) of the superficial digital flexor tendon (SDFT) between Thoroughbreds racehorses that had been in continuous race training and those who had not been in athletic training, the purposes of this study were to determine the relation between normal values of the CSA of the right and left forelimbs SDFT in the metacarpal region for trained and untrained Thoroughbreds racehorses.

\section{MATERIAL AND METHODS}

Twenty clinically normal Thoroughbred racehorses, ranging in age from 2-9 years, 11 males and 9 females were used in this study. Twelve horses were in continuous race training at Sao Paulo Jockey Club. Training regime consisted on 500m trotting and 2000m galloping every morning plus 5-10 minutes hand walking every afternoon. Once a week these horses worked in a high-intensity galloping for $600-2400 \mathrm{~m}$. Eight horses had not been in athletic training for at least 1 year prior to the study. Only horses with ultrasonographic normal tendons were included in the study.

The ultrasonographic examination was performed with horses standing squarely with equal weight on all four limbs. The hair over the palmar aspect of each metacarpal region was shaved, from the base of the accessory carpal bone to the base of the proximal sesamoid bones. Cross-sectional images of normal SDFT were obtained of the palmar aspect metacarpal region of each horse using an ultrasound unit (Aloka SSD-900) with a 7.5MHz linear transducer (Aloka UST-5710-7.5), an acoustic stand-off pad (Sonokit, Sonogel Vertriebs GmbH, Alemanha) and acoustic gel (Carbogel-ULT). Images were performed at $2,4,6,8,10,12,14,16,18,20,24$ and $26 \mathrm{~cm}$ distal to the base of the accessory carpal bone.

For each horse examined, the image of STDF at each level in each limb was outlined freehand, and a value was obtained for CSA $\left(\mathrm{cm}^{2}\right)$. Ultrasonographic images were recorded using a thermal print.

Statistical significance was evaluated using a general linear model in SPSS (version 13, Microsoft). Level, forelimb and group were used as fixed factors for CSA as a dependent variable. Paired t-tests were performed in Instat-Graphpad 3 Software and were used to compare left with right limbs at each level for trained and untrained horses. Statistical significance was set at $\mathrm{P}<0.05$.

\section{RESULTS AND DISCUSSION}

The CSA of the SDFT tendon has been determined in vivo in several studies (SMITH et al., 1994; GILLIS et al., 1995; GENOVESE et al., 1996; REEF, 1998; AGUT et al., 2009); nevertheless, the relation between normal values of the CSA of the right and left forelimbs SDFT for Thoroughbreds racehorses that had been in continuous race training and Thoroughbreds racehorses that had not been in athletic training has not yet been performed.

There was a significant difference between the untrained and trained horses for the CSA at 2, 4, 6, 8, 10, 12 and $14 \mathrm{~cm}$ levels of left forelimb (Figure 1). On the other hand, there was no significant difference between untrained or trained horses for the CSA of right forelimb (Figure 2), excepting the $10 \mathrm{~cm}$ level of right forelimb that had a significant difference because of the elevated CSA of one horse from trained group. KASASHIMA et al. (2002) also documented a significant increase in the rate of cross-sectional area of the superficial digital flexor tendon in Thoroughbred foals from 6 weeks to 15 months of age, with increasing amount of treadmill exercise administered for only a small period each day in addition to pasture exercise. This investigation suggests that tendon is able to respond to exercise during growth. In contrast, our study reports an increase at CSA in Thoroughbred adults horses at continuous race training.

The significance of this is that athletic training results in progressive changes in the molecular and cellular components of the flexor tendons (BIRCH et al., 1999; CHERDCHUTHAM et al., 2001; FIRTH, 2006). Training is a factor that results in adaptive hypertrophic changes in the matrix composition of the tendons, resulting in an increase in CSA, which may remain through the horse's life, (BIRCH et al., 1999; CHERDCHUTHAM et al., 2001). However, it is difficult to say whether tendon hypertrophy represent a beneficial response or very early signs of micro damage. 


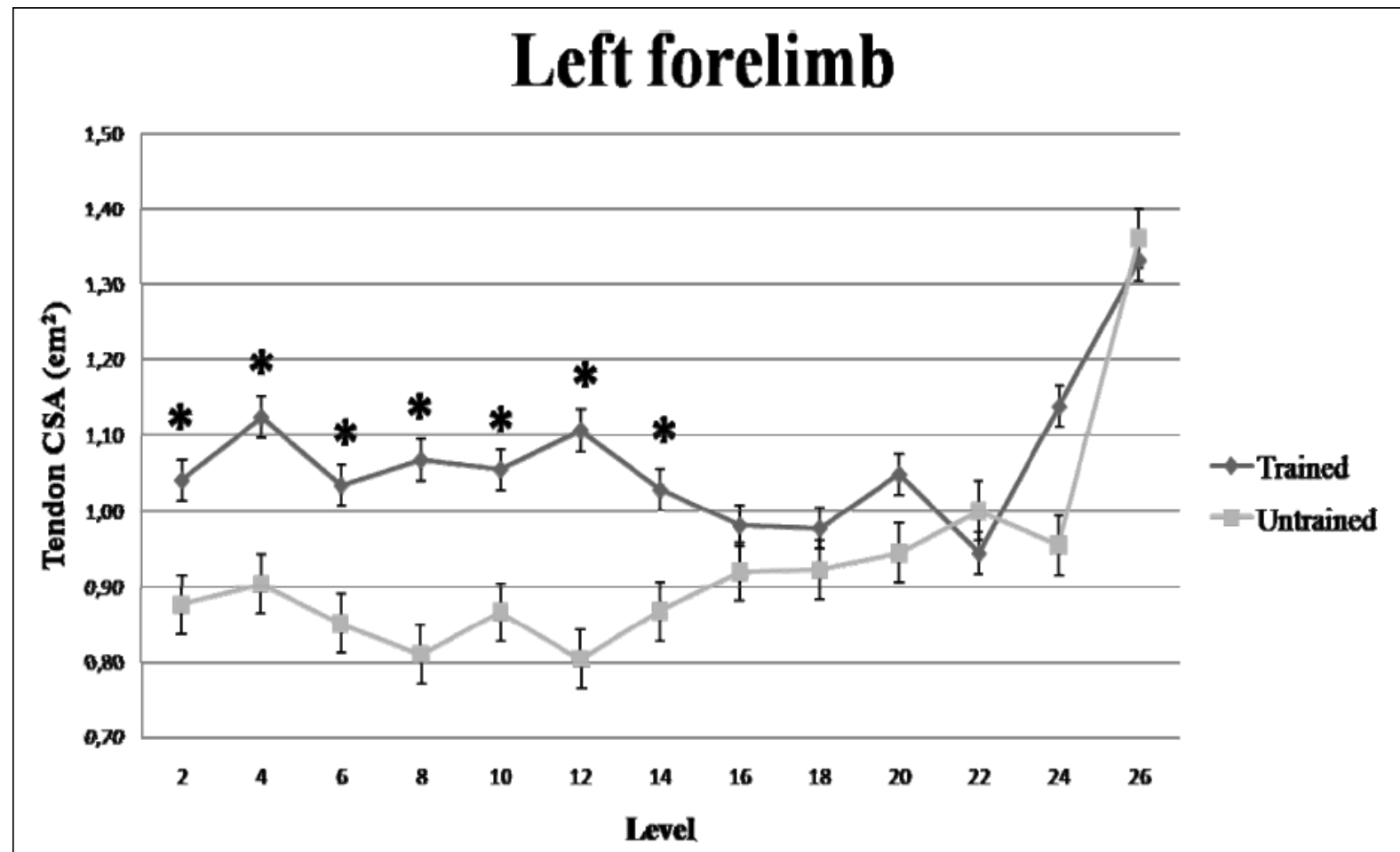

Figure 1 - Ultrasonographic mean cross-sectional areas at each level examined for trained $(n=12)$ and untrained $(n=8)$ Thoroughbreds racehorses of the left forelimb superficial digital flexor. * Significant $(\mathrm{P}<0.05)$ difference.

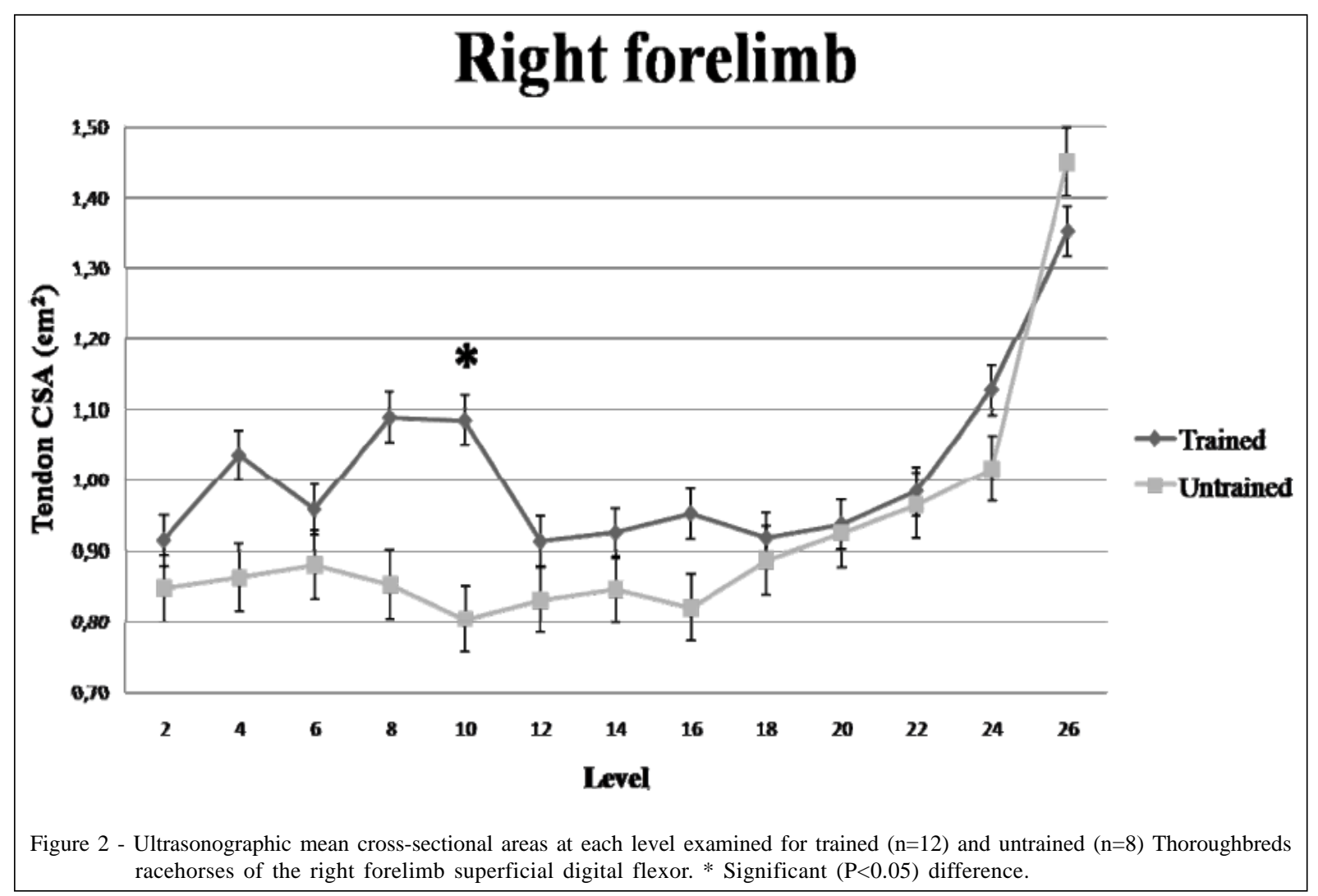

Ciência Rural, v.40, n.8, ago, 2010. 
There was no significant difference $(\mathrm{P}>0.05)$ in CSA between the tendons of the metacarpal region from the 2 to $24 \mathrm{~cm}$ levels distal to the accessory carpal bone. However, at the $26 \mathrm{~cm}$ level distal to the accessory carpal bone, the SDFT was significantly $(\mathrm{P}<0.05)$ larger than others points. DENOIX (1996) asserted that SDFT widens greatly behind the intersesamoidean ligament of the fetlock, so the SDFT was significantly larger at the $26 \mathrm{~cm}$ level because it is anatomically normal. These results are quite similar from the studies performed by AGUT et al. (2009) in which the CSA of the SDFT was similar proximally, and then increased distally so that it was largest at the $24-25 \mathrm{~cm}$ level distal to the accessory carpal bone of Purebred .

The CSA of the SDFT was not significantly different $(\mathrm{P}>0.05)$ between left and right forelimb, at any level, for either trained or untrained horses (Figure 3 and 4). The lack of significant difference between left and right SDFT CSA is in agreement with the research of GILLIS et al. (1995). Because SDFT CSA at each level are similar for left and right forelimbs, examiners may use the opposite forelimb

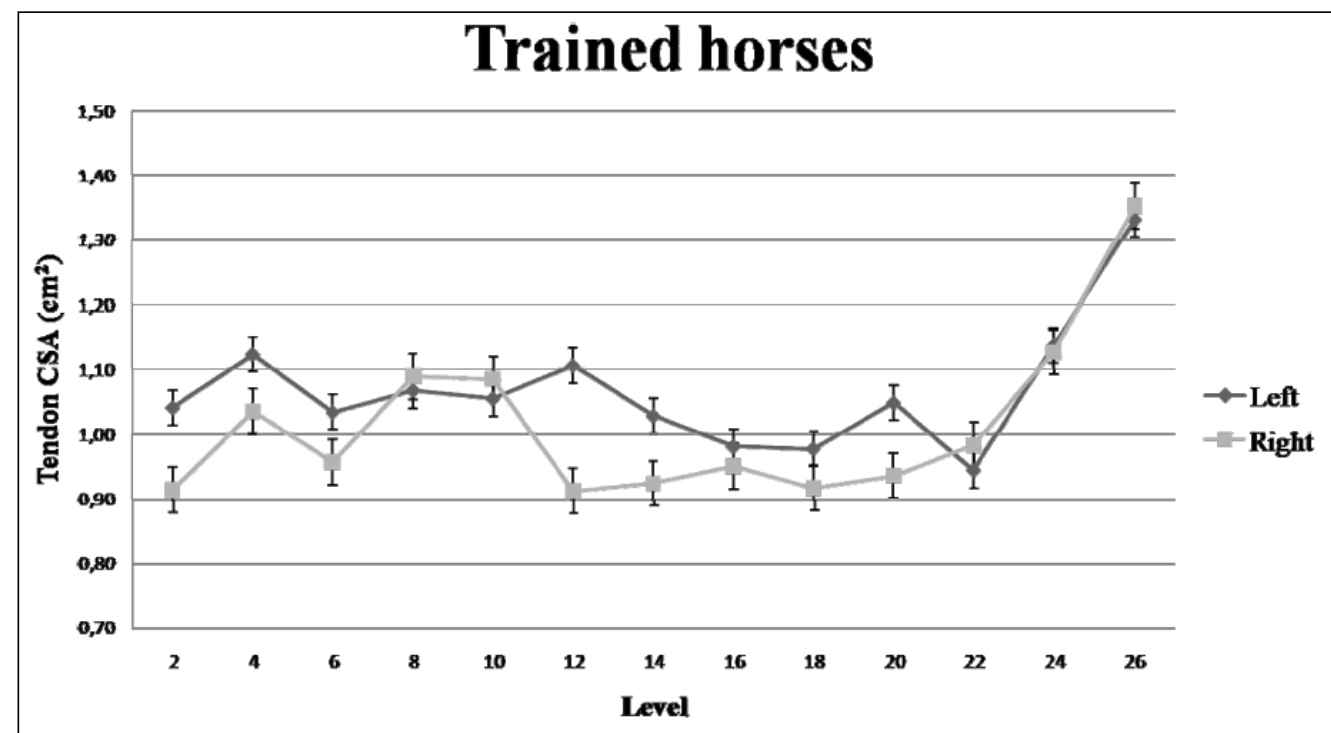

Figure 3 - Ultrasonographic mean cross-sectional areas at each level examined of the left forelimb $(n=12)$ and right forelimb $(n=12)$ superficial digital flexor tendons for trained Thoroughbreds racehorses.

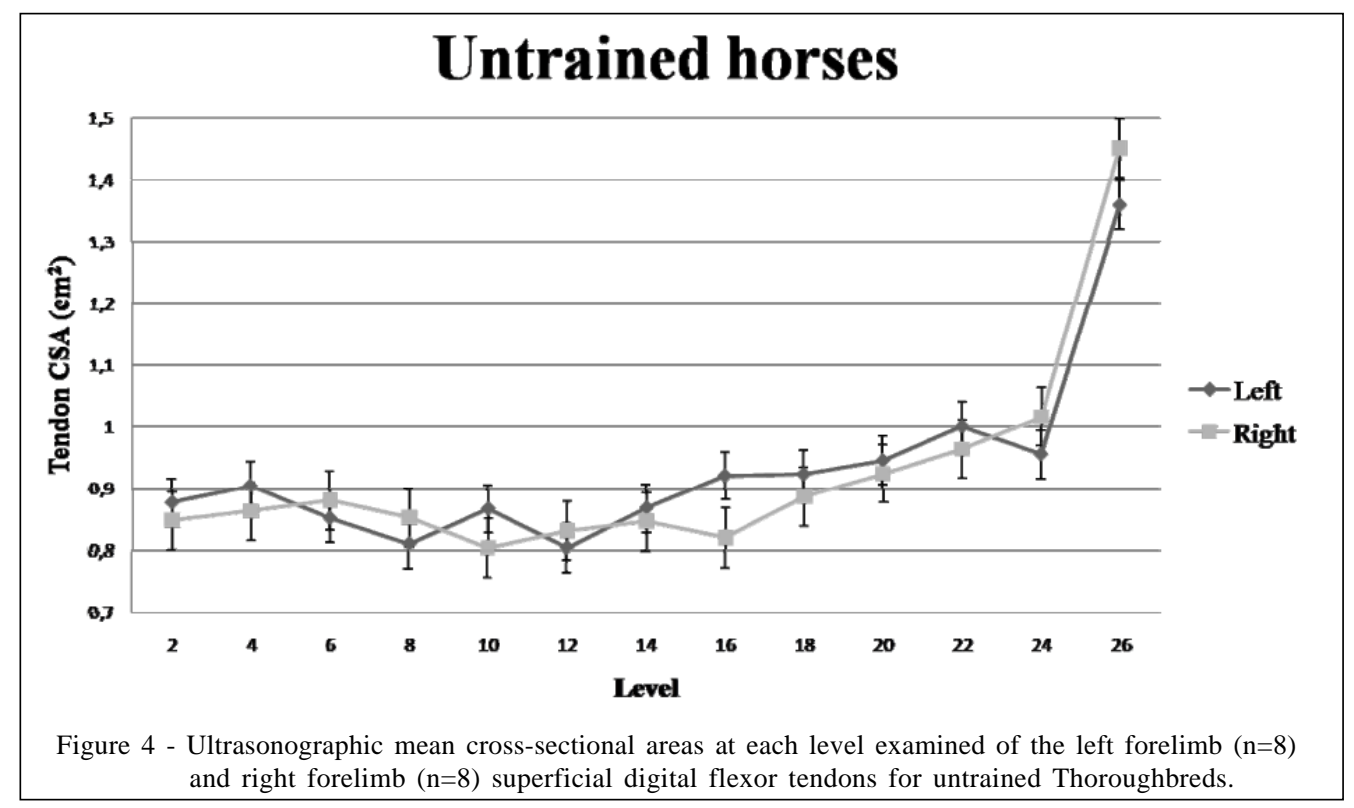

Ciência Rural, v.40, n.8, ago, 2010. 
corresponding tendon at the same level comparison, provided that the injury is unilateral (GILLIS et al., 1995).

\section{CONCLUSION}

The CSA of the left forelimb SDFT for horses that had been in continuous race training remains larger when they train and race anticlockwise, contrary to horses that had not been training for more than one year. In this study, the left forelimb SDFT for trained Thoroughbreds racehorses appears to adapt to race training by increasing ultrasonographic crosssectional area due to the fact that at Sao Paulo Jockey Club Thoroughbreds racehorses train and race anticlockwise.

\section{ACKNOWLEDGEMENTS}

The authors thanks for "Fundação de Amparo à Pesquisa do Estado de São Paulo” (FAPESP) for their substantial contributions to funding this project.

\section{ANIMAL CARE AND ETHICS COMMITTEE}

The project was approved by the Animal Care and Ethics Committee of the Veterinary Medicine and Zootechny School of São Paulo University, protocol number $957 / 2006$.

\section{REFERENCES}

AGUT, A. et al. Ultrasonographic characteristics (crosssectional area and relative echogenicity) of the digital flexor tendons and ligaments of the metacarpal region in Purebred Spanish horses. Veterinary Journal, v.180, p.377-383, 2009. Available from: http://www.sciencedirect.com/ science?_ob=ArticleURL\&_udi=B6WXN-4S7HWRJ18 user $=10 \&$ \&_coverDate $=06 \% 2 \mathrm{~F} 30 \% 2 \mathrm{~F} 2009$ \&_rdoc $=1$ \&_fmt=high\&_orig=se arch\&_sort $=$ d\&_docanchor $=\&$ view $=$ c\&_acct $=$ C000050221\& _version $=1 \&$ _urlVersion $=0$ \&_userid $=10 \& \mathrm{md} 5=8 \mathrm{a} 1 \mathrm{c} 4 \mathrm{~d} 79 \mathrm{db}$ bb77f11ec1c66b97b621d6. Accessed: Jun. 20, 2010. doi:10.1016/j.tvjl.2008.01.012.

BIRCH, H.L. et al. Age-related changes to the molecular and cellular components of equine flexor tendons. Equine Veterinary Journal, v.31, p.391-396, 1999. Available from: http://www3.interscience.wiley.com/cgi-bin/fulltext/ 123378193/PDFSTART. Accessed: Jun. 20, 2010. doi: 10.1111/j.2042-3306.1999.tb03838.x.

CHERDCHUTHAM, W. et al. Effects of exercise on biomechanical properties of the superficial digital flexor tendon in foals. American Journal of Veterinary Research, v.62, p.1859-1864, 2001. Available from: http:/ /avmajournals.avma.org/doi/pdf/10.2460/ajvr.2001.62.1859. Accessed: Jun. 20, 2010. doi: 10.2460/ajvr.2001.62.18

DENOIX, J.M. Functional anatomy of tendons and ligaments in the distal limbs (manus and pes). In: DUBAI
INTERNATIONAL EQUINE SYMPOSIUM, 1996, Dubai. Proceedings... Dubai: Mathews R. Rantanen Design, 1996. p.23-53.

FIRTH, E.C. The response of bone, articular cartilage and tendon to exercise in the horse. Review. Journal of Anatomy, v.208, p.513-526, 2006. Available from: http:// www.ncbi.nlm.nih.gov/pmc/articles/PMC2100207/pdf/ joa0208-0513.pdf. Accessed: Jun. 20, 2010. doi: 10.1111/ j.1469-7580.2006.00547.x.

GENOVESE, R.L. et al. Clinical experience with quantitative analysis of superficial digital flexor tendon injuries in Thoroughbred and Standardbred racehorses. Veterinary Clinics of North America: Equine Practice, v.1, p.129147, 1990 .

GENOVESE, R.L et al. Superficial digital flexor tendonitis long-term sonographic and clinical study of racehorses. In: DUBAI INTERNATIONAL EQUINE SYMPOSIUM, 1996, Dubai. Proceedings... Dubai: Mathews R. Rantanen Design, 1996. p.187-205.

GILLIS, C.L. et al. Ultrasonographically detected changes in equine superficial digital flexor tendons during the first months of race training. American Journal of Veterinary Research, v.54, n.11, p.1797-1802, 1993.

GILLIS, C.L. et al. Ultrasonographic cross-sectional area and mean echogenicity of the superficial and deep digital flexor tendons in 50 trained Thoroughbred racehorses. American Journal of Veterinary Research, v.56, n.10, p.1265-1269, 1995.

RANTANEN, N.W. The use of diagnostic ultrasound in limb disorders of the horse: a preliminary report. Journal of Equine Veterinary Science, v.12, n.2, p.62-64, 1982. Available from: http://www.sciencedirect.com/ science?_ob=MImg\&_imagekey=B75GX-4PPDJW0-51\&_cdi $=13106 \&$ \&user $=10 \&$ \&ii $=$ S073708068280021X\&_or ig=browse\&_coverDate $=12 \% 2 F 31 \% 2 F 1982 \&$ \&k=99997999 $7 \& \mathrm{v}$ i e w $=$ c \& w c h p $=$ d G L z V z b zSkWb\&md5=2ea2f3ed52366f7af2d4485c5a99fd03\&ie=/ sdarticle.pdf. Accessed: Jun. 20, 2010. doi:10.1016/S07370806(82)80021-X.

RANTANEN, N.W. et al. Ultrasonographic evaluation of the equine limb: technique. In: ROSS, M.W.; DYSON, S.J. Diagnosis and management of lameness in the horse. Missouri: Saunders, 2003. p.166-188.

REEF, V.B. Musculoskeletal ultrasonography. In: REEF, V.B. Equine diagnostic ultrasound. Philadelphia: Saunders, 1998. p.39-186.

REEF, V.B. Superficial digital flexor tendon healing: ultrasonographic evaluation of therapies. Veterinary Clinic North America: Equine Practice, v.17, p.159-179, 2001.

SMITH, R.K.W. et al. The cross-sectional areas of normal equine digital flexor tendons determined ultrasonographically. Equine Veterinary Journal, v.26, p.460-465, 1994. Available from: http://www3.interscience.wiley.com/cgi-bin/ fulltext/123377497/PDFSTART. Accessed: Jun. 20, 2010. doi: 10.1111/j.2042-3306.1994.tb04050.x. 